\title{
Identifikasi Pipa Metal Bawah Permukaan Menggunakan Metode Ground Penetrating Radar (GPR)
}

Arkadia Luga ${ }^{\mathrm{a}}$, Okto Ivansyah ${ }^{\mathrm{b}}$, Muliadi ${ }^{\mathrm{a}}$

Jurusan Fisika, FMIPA Universitas Tanjungpura, Jalan Prof. Dr. Hadari Nawawi, Pontianak, bPoliteknik Negeri Pontianak, Jalan Ahmad Yani, Pontianak, Indonesia

*Email : oktoivansyah@yahoo.com

\begin{abstract}
Abstrak
Telah dilakukan penelitian identifikasi pipa metal menggunakan metode GPR, berdasarkan hasil penampang radargram 2D yang diolah sampai dengan tahap migrasi. Pada penelitian ini digunakan data GPR yang terdiri dari empat lintasan. Data yang telah diolah menghasilkan penampang radargram yang menggambarkan hasil refleksi dari objek-objek dan lapisan bawah permukaan tanah, dari refleksi tersebut dapat diketahui bentuk refleksi, kecerahan amplitudo, nilai kurva kecepatan perambatan gelombang elektromagnetik, letak serta kedalaman dari objek yang terdeteksi pada saat pengambilan data GPR. Pada penampang radargram lintasan 1 diperoleh dua bentuk refleksi yang diduga sebagai titik keberadaan pipa metal, titik pertama berada pada jarak 72,15 meter dari titik awal pengambilan data pada kedalaman 0,704 meter di bawah permukaan dan Two-Way Time (TWT) 14 ns, serta titik kedua berada pada 73,78 meter dari titik awal pengambilan data pada kedalaman 0,754 meter dan TWT 15 ns. Pada lintasan 2 diperoleh dua bentuk refleksi yang diduga sebagai titik keberadaan pipa metal, titik pertama berada pada jarak 22,05 meter dari titik pertama pengambilan data dengan kedalaman 0,8 meter di bawah permukaan pada TWT 16 ns, serta titik kedua terletak pada jarak 23,94 meter dari titik awal pengambilan data dengan kedalaman 0,6 meter di bawah permukaan pada TWT $11 \mathrm{ns,} \mathrm{dengan} \mathrm{nilai}$ kecepatan perambatan gelombang elektromagnetik pada material 0,1980 m/ns.
\end{abstract}

Kata Kunci : Pipa Metal, Penampang Radargram, Metode GPR, Gelombang Elektromagnetik.

\section{Latar Belakang}

Georadar atau GPR adalah salah satu metode geofisika yang bertujuan untuk mencitrakan kondisi bawah permukaan bumi dengan menggunakan prinsip penjalaran gelombang elektromagnetik dalam merekam corak dan karakteristik bawah permukaan. Beberapa kelebihan dari metode ini antara lain bersifat tidak merusak, dan memiliki resolusi tinggi. Kekurangannya adalah kedalaman penetrasi terbatas hanya sampai beberapa puluh meter saja bergantung pada frekuensi antena transmitter yang digunakan. Alat GPR dapat mengirim pulsa berupa gelombang elektromagnetik dengan frekuensi antara 10$1000 \mathrm{MHz}$. Metode ini telah banyak digunakan dalam berbagai bidang seperti arkeologi, teknik sipil, forensik, geologi dan utilitas deteksi [1].

Metode GPR merupakan metode yang digunakan dalam penelitian bawah permukaan yang dangkal. Penetrasi kedalaman pada metode GPR sangat berpengaruh pada sifat kelistrikan lapisan bawah permukaan, dengan prinsip kerja pengiriman dan penerimaan pulsa gelombang elektromagnetik, sehingga jika terdapat anomali pada lapisan bawah permukaan kita dapat mendeteksi struktur lapisan tersebut pada radargram [2].

Besarnya penetrasi atau kedalaman yang dapat dicapai oleh gelombang radar sangat bergantung pada besar kecilnya frekuensi yang digunakan. Semakin kecil frekuensi antena transmitter yang digunakan, maka akan semakin besar penetrasi yang dicapai oleh gelombang radar dan sebaliknya. Ketika gelombang radar dipancarkan dari transmitter akan menghasilkan gelombang refleksi dengan amplitudo yang berbeda-beda. Amplitudo gelombang refleksi yang terekam di receiver tergantung pada sifat elektromagnetik dari benda yang ada dibawah permukaan yang dilewati oleh gelombang radar. Sifat elektromagnetik dari berbagai material yang ada dibawah permukaan sangat berhubungan dengan komposisi mineral yang ada dibawah permukaan.

Berdasarkan uraian di atas pada penelitian ini metode GPR digunakan untuk mengidentifikasi kenampakan pipa metal bawah permukaan, berdasarkan radargram 2D hasil pengolahan data yang dilakukan sampai dengan proses migrasi. Identifikasi dilakukan berdasarkan ciri-ciri kenampakan pipa metal seperti bentuk refleksi, tinggi rendahnya kecerahan (amplitudo) refleksi, serta nilai analisis kecepatan pada medium pipa metal. 


\section{Metodologi}

Data yang digunakan berjumlah empat lintasan, data diambil dengan antena transmitter berfrekuensi $500 \mathrm{MHz}$. Pengukuran GPR pada penelitian ini menggunakan konfigurasi radar reflection profiling dimana antena transmitter dan receiver bergerak secara bersamaan dan tampilan pada radargram merupakan kumpulan dari tiap titik pengamatan [3]. Konfigurasi radar reflection profiling merupakan mode monostatik dimana transmitter dan receiver digabung dalam satu antena [4].

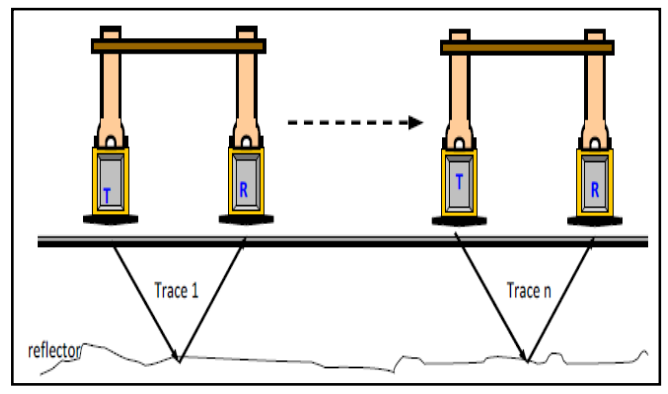

Gambar 1. Konfigurasi radar reflection profiling [5]

Prinsip kerja GPR dengan memanfaatkan gelombang elektromagnetik yang dikirimkan kemudian dipantulkan karena mengenai objek tertentu. Hasil pantulan ini yang kemudian direkam [6]. Pulsa radar diteruskan, dipantulkan dan dihamburkan oleh struktur permukaan dan anomali di bawah permukaan. Gelombang EM yang dipantulkan dan dihamburkan diterima oleh antena penerima di permukaan bumi dalam bentuk karakteristik amplitudo gelombang (radargram) [7].

Untuk mendeteksi suatu objek diperlukan suatu perbedaan karakteristik parameter kelistrikan seperti permitivitas listrik, konduktivitas, dan permeabilitas magnetik. Beberapa contoh objek yang memiliki kontras sifat elektromagnetik yang cukup besar adalah buried tanks, sedimentary layers, water table, dan sebagainya [8]. Kedalaman penetrasi metode GPR sangat bergantung pada sifat kelistrikan material yang diselidiki seperti konduktivitas listrik dan konstanta dielektrik. Nilai konduktivitas lapisan tanah sangat dipengaruhi oleh material-material penyusun tanah itu sendiri. Kandungan air dan $\mathrm{pH}$ dari lapisan tanah juga sangat mempengaruhi perubahan nilai konduktivitas lapisan tanah [9].

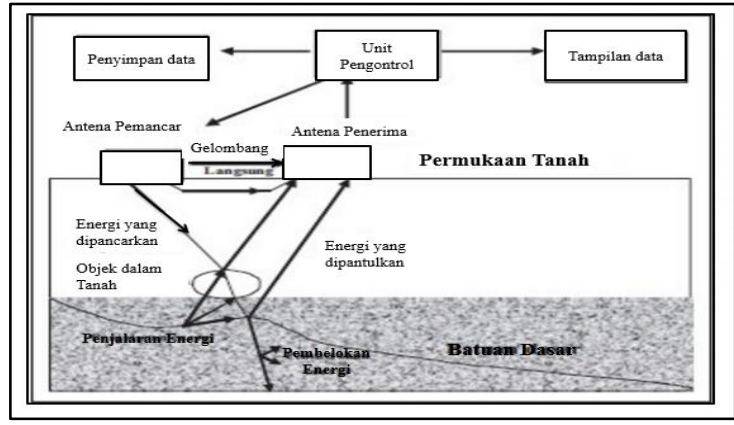

Gambar 2. Blok prinsip kerja GPR [10]

Kecepatan gelombang elektromagnet pada medium tergantung pada frekuensi, konduktivitas listrik, konstanta dielektrik dan permeabilitas magnet, yang secara matematis diturunkan sebagai berikut:

$V_{m}=\frac{\omega}{\beta}=\frac{c}{\sqrt{\frac{\varepsilon_{r} \mu_{r}}{2} \sqrt{1+\tan ^{2} D}+1}} \quad(\mathrm{~m} / \mathrm{ns})$

Dimana c adalah kecepatan cahaya di udara, $\varepsilon_{r}$ adalah konstanta dielektrik relatif dan $\mu_{r}$ adalah permeabilitas magnetik relatif $\tan ^{2} D$ merupakan loss factor.

$$
\tan ^{2} D=\frac{\sigma}{\varepsilon \varpi}
$$

Sebagian besar medium bawah permukaan kurang bersifat magnet $\left(\mu_{r}=1\right)$ dan merupakan material dengan konduktivitas yang kecil $(\sigma=0)$, maka kecepatan gelombang dapat dituliskan sebagai berikut [3]. :

$$
V_{m}=\frac{c}{\sqrt{\varepsilon_{r}}}=\frac{0,3}{\sqrt{\varepsilon_{r}}}(\text { meter } / \text { nanosekon })
$$




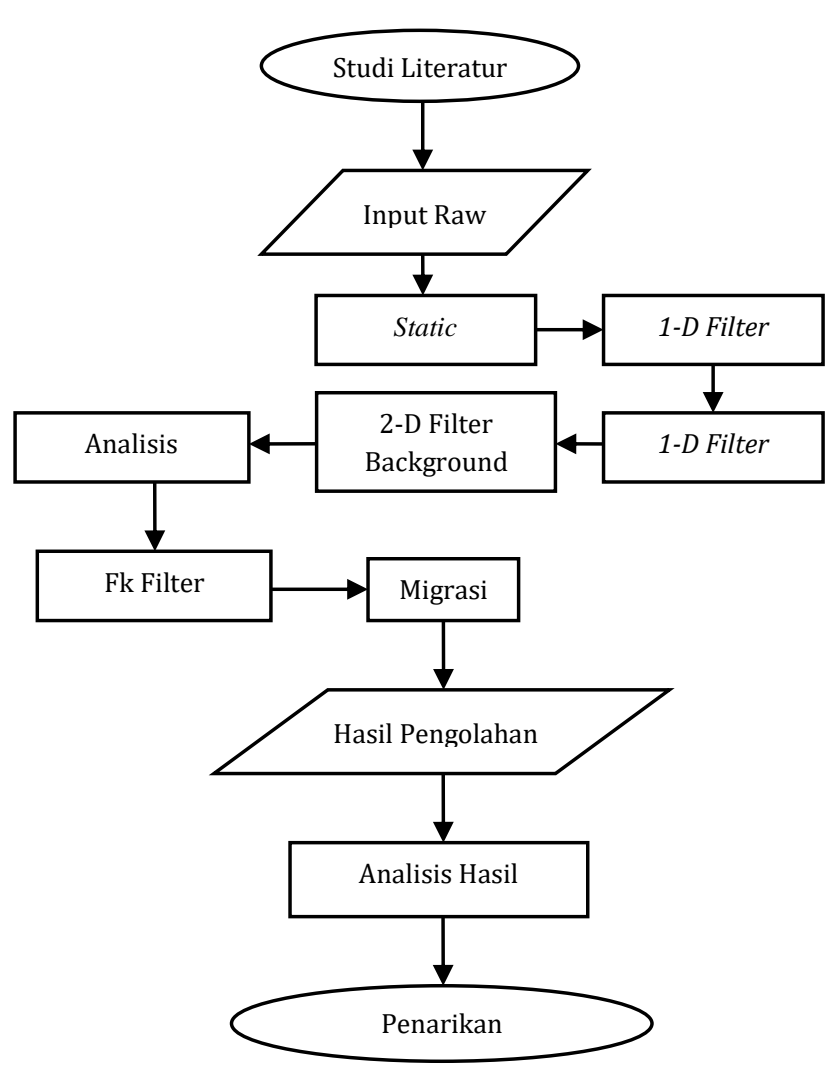

Gambar 3. Diagram Alir Penelitian

Pengolahan data GPR dilakukan dengan tujuan untuk menghasilkan profil penampang GPR yang baik, sehingga berdasarkan penampang GPR tersebut dapat ditafsirkan keadaan dan bentuk dari lapisan-lapisan (reflector) batuan dan utilitas sesuai dengan target yang diinginkan. Tahap pengolahan data GPR yang telah dilakukan terdiri dari input data, static correction, dewow, gain, background removal, analisis kecepatan, $f-k$ filter, dan migrasi. Pada bagian ini dibahas langkahlangkah yang digunakan dalam penelitian.

1. Input data merupakan proses pemasukan data dari raw data hasil perekaman (recording).

2. Static Correction dilakukan dengan tujuan agar radargram yang kita lihat sesuai dengan topografi daerah survei, sehingga radargram yang kita lihat mendekati keadaan sebenarnya.

3. Dewow adalah langkah processing yang dilakukan untuk menghilangkan frekuensi yang sangat rendah yang terekam dalam radargram.

4. Gain bertujuan untuk melakukan penguatan kembali amplitudo yang hilang sedemikian rupa sehingga seolah-olah pada setiap titik memiliki energi yang sama.
5. Background removal proses ini bertujuan untuk menghilangkan noise yang selalu muncul secara konsisten pada seluruh profil sehingga menutupi sinyal yang sebenarnya pada arah mendatar.

6. Analisis kecepatan merupakan penentuan kecepatan perambatan gelombang elektromagnetik pada material bawah permukaan, kemudian mengubah travel time ke kedalaman penetrasi.

7. Fk-Filter adalah filter dua dimensi yang akan memfilter frekuensi temporal dan spasial.

8. Migrasi adalah suatu prosedur untuk mengubah permukaan yang telah terekam dalam data GPR dengan lokasi Heterogenesis bawah permukaan pada posisi yang benar atau dalam kata lain upaya pengembalian reflektor-reflektor yang miring pada posisi yang sebenarnya.

Identifikasi atau analisis data dilakukan pada penampang radargram 2D yang telah diolah sampai dengan tahap migrasi. Berdasarkan [11] menunjukkan bahwa ketika gelombang elektromagnetik yang dihasilkan oleh antenna transmitter melewati suatu medium seperti pipa, kabel dan rebar maka data yang diterima oleh antenna receiver akan berbentuk $\mathrm{U}$ atau $\mathrm{V}$ terbalik. Hal ini terjadi karena ketika antenna memancarkan gelombang dan ketika gelombang direfleksikan akan membentuk lintasan yang menyerupai kerucut sehingga target dapat terdeteksi dimana puncak kerucut merupakan letak keberadaan objek terdeteksi.

Bentuk hiperbola yang dihasilkan pada saat pengukuran sangat dipengaruhi oleh dua hal yaitu [12] :

1. Spasi scan

Jika spasi scan yang digunakan besar maka akan diperoleh hasil pendeteksian dengan bentuk hiperbola yang kecil, begitupun sebaliknya jika spasi scan yang digunakan kecil akan dihasilkan hasil pendeteksian dengan bentuk hiperbola yang luas atau besar.

2. Kecepatan sinyal gelombang
elektromagnetik

Kecepatan gelombang elektromagnetik ketika melewati suatu bahan sangat bergantung pada nilai konstanta dielektrik, ketika kecepatan gelombang elektromagnetik tinggi (nilai konstanta dielektrik bahan rendah) akan dihasilkan bentuk pendeteksian dengan hiperbola yang lebih luas atau besar, begitupun sebaliknya ketika kecepatan gelombang elektromagnetik rendah (nilai konstanta dielektrik bahan tinggi) akan dihasilkan bentuk pendeteksian dengan hiperbola yang lebih sempit atau kecil.

Kecerahan (amplitudo) dari refleksi hiperbolik juga dipengaruhi oleh nilai 
konduktivitas bahan, benda-benda logam memiliki nilai kecerahan (amplitudo) lebih kuat jika dibandingkan dengan benda-benda dengan bahan lainnya seperti pipa PVC walaupun memiliki bentuk refleksi yang hampir sama dengan pipa metal, namun kecerahan (amplitudo) lebih rendah, selain konduktivitas besar diameter target juga berpengaruh terhadap kecerahan refleksi, jika diameter target besar maka akan dihasilkan nilai kecerahan (amplitudo) tinggi begitu pula sebaliknya jika diameter target kecil maka nilai kecerahan refleksi yang dihasilkan juga rendah.

\section{Hasil dan Pembahasan}

Pada penelitian ini akan dibahas mengenai kenampakan pipa metal bawah permukaan berdasarkan hasil pengolahan data GPR dengan bentuk penampang 2D yang telah diolah sampai dengan tahap migrasi. Identifikasi atau analisis keberadaan pipa dari masing-masing lintasan akan dibahas pada uraian berikut :

\subsection{Lintasan 1}

Pada profil radargram lintasan 1 data diambil dengan frekuensi antena transmitter $500 \mathrm{MHz}$, panjang lintasan 91 meter dan kedalaman penetrasi gelombang elektromagnetik \pm 3 meter. Pada profil radargram yang telah diolah sampai dengan proses background removal dan analisis kecepatan (Gambar 1) terlihat dua anomali yang cukup kontras dengan pola refleksi hiperbola terlihat pada dua titik yaitu pada TWT 14 ns dan 15 ns dimana kedua pola difraksi tersebut jika dicocokkan dengan kurva kecepatan perambatan gelombang elektromagnetik pada material diperoleh nilai 0,1980 m/ns. Nilai kecerahan (amplitudo) yang cukup tinggi juga ditunjukkan pada kedua pola refleksi dan lapisan bawah permukaan, hal ini menunjukkan sifat material bawah permukaan berupa perbedaan nilai konduktivitas listrik dan konstanta dielektrik. Nilai konduktivitas listrik memiliki nilai yang berkebalikan dengan nilai konstanta dielektrik, kedua sifat material ini sangat mempengaruhi nilai kecerahan (amplitudo) pada hasil pengolahan data GPR. Nilai konduktivitas listrik material menunjukkan kemampuan material dalam menghantarkan listrik. Material dengan nilai konduktivitas listrik tinggi seperti bahan-bahan logam akan menghasilkan nilai kecerahan (amplitudo) yang tinggi, begitu pula sebaliknya jika nilai konduktivitas listrik material rendah maka akan dihasilkan nilai kecerahan (amplitudo) yang rendah pula. Nilai konstanta dieletrik material memiliki hubungan dengan kecepatan perambatan gelombang elektromagnetik pada material. Material dengan nilai konstanta dielektrik rendah memiliki nilai kecepatan perambatan gelombang elektromagnetik tinggi. Begitu pula sebaliknya material dengan nilai konstanta dielektrik tinggi memiliki nilai kecepatan perambatan gelombang elektromagnetik yang rendah. Hal ini menunjukkan bahwa nilai konstanta dielektrik material berbanding terbalik dengan kecepatan perambatan gelombang elektromagnetik pada material, namun untuk konduktivitas listrik material memiliki nilai yang berbanding lurus dengan kecepatan perambatan gelombang elektromagnetik pada material. Untuk nilai kecerahan (amplitudo) dengan nilai kecerahan tinggi memiliki arti bahwa material terdeteksi memiliki nilai konduktivitas listrik yang tinggi.

Pada profil radargram yang telah diproses sampai dengan tahap background removal dan analisis kecepatan (Gambar 1) akan dilakukan analisis terhadap refleksi dengan bentuk $U$ atau $\mathrm{V}$ terbalik yang diduga sebagai refleksi kenampakan pipa yang berada dibawah permukaan. Nilai kecerahan (amplitudo) yang dihasilkan sangat tinggi hal ini menunjukan sifat konduktivitas bahan yang tinggi dan mengindikasikan bahwa objek yang terdeteksi berasal dari bahan logam. Pola refleksi hiperbola tersebut terlihat pada TWT 14 ns dan 15 ns, berdasarkan hasil pengolahan yang dilakukan pada proses analisis kecepatan dan pencocokan dengan kurva kecepatan diperoleh harga kecepatan 0,1980 m/ns. Hasil pencocokan dengan kurva kecepatan tersebut menunjuakan kecepatan yang tinggi dan bentuk hiperbola yang luas hal ini mengindikasikan bahwa nilai konstanta dielektrik material yang terdeteksi bernilai rendah. Pada kedua pola refleksi tersebut diperoleh bentuk yang sama. Pola refleksi yang terlihat pada TWT 14 ns dan 15 ns diindikasikan sebagai refleksi dari pipa metal yang dipasang dibawah permukaan tanah dengan pemasangan yang dilakukan secara berdekatan. Pada TWT 14 ns keberadaan pipa diindikasikan pada jarak 72,15 meter dari titik awal pengambilan data dan kedalaman 0,704 meter dibawah permukaan. Sedangkan pada TWT 15 ns berjarak 73,78 meter dari titik awal pengambilan data dan pada kedalaman 0,754 meter dibawah permukaan. Kedua refleksi yang di hasilkan pada dua titik di lintasan 1 memiliki nilai kurfa kecepatan yang sama hal ini mengindikasikan bahwa dua pipa yang di pasang berdekatan ini memiliki material pembuatan yang sama yaitu bahan metal, bentuk refleksi hiperbola dan nilai kecerahan (amplitudo) yang dihasilkan juga sama.

Pada (Gambar 2) dapat dilihat secara lebih jelas titik-titik yang diduga sebagai keberadaan pipa metal, gambar ini merupakan hasil 
pengolahan data pada tahapan terakhir yaitu migrasi. Pada lintasan pertama ini digunakan migrasi dengan metode diffraction stack pada tahap ini boleh digunakan nilai kecepatan yang bervariasi untuk mengetahui difraksi pipa mencapai nilai optimum pada kecepatan berapa.
Pada tahapan ini migrasi dilakukan dengan nilai kecepatan yang digunakan yaitu 0,3 m/ns, karena pada kecepatan ini dianggap difraksi dapat mencapai nilai maksimum dengan kurva kecepatan yang dihasilkan oleh refleksi pipa adalah $0,1980 \mathrm{~m} / \mathrm{ns}$.

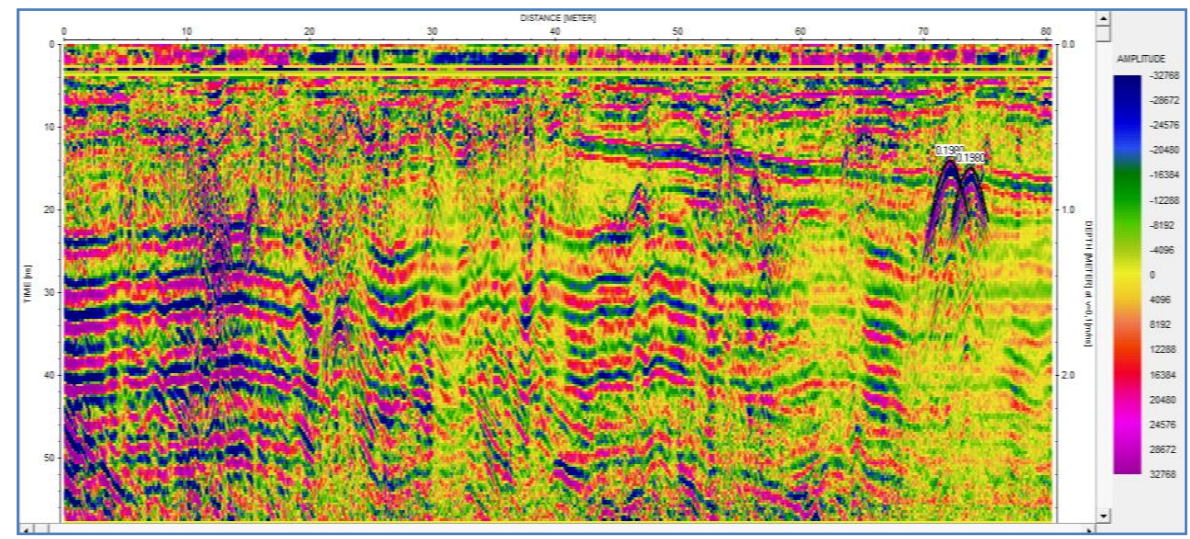

Gambar 3 Tampilan radargram lintasan 1 setelah proses background removal dan analisis kecepatan

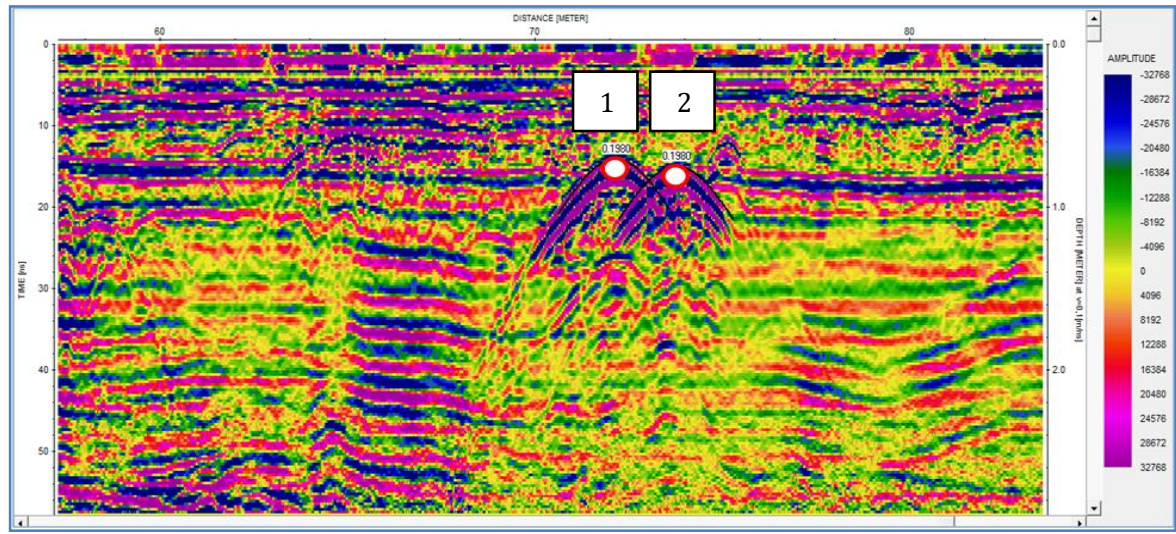

Gambar 4 Tampilan radargram lintasan 1 setelah proses migrasi.

\subsection{Lintasan 2}

Pada profil radargram lintasan 2 data diambil dengan antenna transmitter dengan frekuensi $500 \mathrm{MHz}$, dengan panjang lintasan 90 meter, dan kedalaman penetrasi gelombang elektromagnetik \pm 3 meter. Pada profil radargram yang telah diolah sampai pada tahap backgroun removal dan analisis kecepatan (Gambar 3) terlihat anomali dengan bentuk refleksi hiperbola pada delapan titik terjadi pada TWT pada titik pertama 24 ns, pada titik kedua 10 ns, pada titik ketiga 29 ns, pada titik keempat 13 ns, pada titik kelima 16 ns, pada titik keenam 11 ns, pada titik ketujuh 14 ns, dan pada titik kedelapan 9 ns. Dimana pola-pola difraksi ini ketika dicocokan dengan kurva perambatan gelombang elektromagnetik pada material akan memperoleh nilai kecepatan masing - masing pada titik pertama, titik ketiga, titik keempat dan titik ketujuh diperoleh nilai $0,1150 \mathrm{~m} / \mathrm{ns}$. Pada titik kedua dan titik kedelapan diperoleh nilai 0,1300 m/ns. Pada titik kelima dan titik keenam diperoleh nilai $0,1980 \mathrm{~m} / \mathrm{ns}$.

Pada kedelapan titik ini juga menunjukan nilai kecerahan (amplitudo) yang cukup tinggi pada pola refleksi dan lapisan bawah permukaan, hal ini menunjukan sifat material bawah permukaan berupa perbedaan nilai konduktivitas listrik dan konstanta dielektrik. Nilai konduktivitas listrik memiliki nilai yang berkebalikan dengan nilai konstanta dielektrik, kedua sifat material ini sangat mempengaruhi nilai kecerahan (amplitudo) pada hasil pengolahan data GPR. Nilai konduktivitas listrik material menunjukan kemampuan material dalam menghantarkan listrik. Material dengan nilai konduktivitas listrik tinggi seperti bahanbahan logam akan menghasilkan nilai kecerahan (amplitudo) yang tinggi, begitu pula sebaliknya jika nilai konduktivitas listrik material rendah maka akan dihasilkan nilai kecerahan 
(amplitudo) yang rendah pula. Nilai konstanta dieletrik material memiliki hubungan dengan kecepatan perambatan gelombang elektromagnetik pada material, material dengan nilai konstanta dielektrik rendah memiliki kecepatan perambatan gelombang elektromagnetik tinggi begitu pula sebaliknya material dengan nilai konstanta dielektrik tinggi memiliki kecepatan perambatan gelombang elektromagnetik yang rendah, hal ini menunjukan bahwa nilai konstanta dielektrik material berbanding terbalik dengan kecepatan perambatan gelombang elektromagnetik pada material, namun untuk konduktivitas listrik material memiliki nilai yang berbanding lurus dengan kecepatan perambatan gelombang elektromagnetik pada material. Untuk nilai kecerahan (amplitudo) dengan nilai kecerahan tinggi memiliki arti bahwa material terdeteksi memiliki nilai konduktivitas listrik yang tinggi.

Pada profil radargram yang telah diproses sampai dengan tahap background removal dan analisis kecepatan akan dilakukan analisis terhadap refleksi dengan bentuk $\mathrm{U}$ atau $\mathrm{V}$ terbalik yang diduga sebagai refleksi kenampakan pipa yang berada dibawah permukaan tanah. Pada titik pertama, titik ketiga, titik keempat, dan titik ketujuh diperoleh kecepatan perambatan gelombang elektromagnetik 0,1150 m/ns, berdasarkan nilai tersebut pipa yang tertanam dibawah permukaan ini diindikasikan sebagai pipa dengan bahan karet. Pada titik pertama indikasi keberadaan pipa ditemukan pada 0,37 meter dari titik awal pengambilan data dan kedalaman 1,225 meter dibawah permukaan, pada titik ketiga ditemukan pada 7,9 meter dari titik awal pengambilan data dan 1,49 meter dibawah permukaan tanah, pada titik keempat ditemukan pada jarak 14,89 meter dari titik awal pengambilan data dan 0,66 meter di bawah permukaan tanah, dan pada titik ke tujuh ditemukan pada jarak 34,05 meter dari titik awal pengambilan data dan 0,695 meter dibawah permukaan tanah.

Profil radargram dengan bentuk refleksi U atau $\mathrm{V}$ terbalik juga terjadi pada titik kedua dan titik kedelapan, pada kedua titik ini diperoleh kecepatan perambatan gelombang elektromagnetik $0,1300 \mathrm{~m} / \mathrm{ns}$, berdasarkan nilai tersebut diindikasikan bahwa pipa yang berada dibawah permukaan ini merupakan pipa dengan bahan PVC. Pada titik kedua indikasi keberadaan pipa ditemukan pada jarak 3,67 meter dari titik awal pengambilan data dan 0,5187 meter dibawah permukaan tanah, dan pada titik kedelapan indikasi keberadaan pipa ditemukan pada jarak 36,11 meter dari titik awal pengambilan data dan 0,458 meter dibawah permukaan tanah.

Profil radargram dengan bentuk refleksi U dan $\mathrm{V}$ terbalik yang terjadi pada titik kelima dan keenam memiliki kecepatan perambatan gelombang elektromagnetik tertinggi pada lintasan kedua yaitu mencapai nilai 0,1980 $\mathrm{m} / \mathrm{ns}$, berdasarkan nilai ini diindikasikan pada dua titik ini terdapat pipa dengan bahan metal. Pada titik ke lima indikasi keberadaan pipa ditemukan pada jarak 22,05 meter dari titik awal pengambilan data dan kedalaman 0,8 meter dibawah permukaan tanah, dan pada titik keenam indikasi keberadaan pipa ditemukan pada jarak 23,94 meter dari titik awal pengambilan data dan kedalaman 0,6 meter dibawah permukaan tanah. Pada (Gambar 4) dapat dilihat hasil pengolahan data pada tahapan terakhir yaitu migrasi. Pada lintasan kedua ini juga digunakan migrasi dengan metode diffraction stack dengan nilai kecepatan yang digunakan yaitu $0,3 \mathrm{~m} / \mathrm{ns}$.

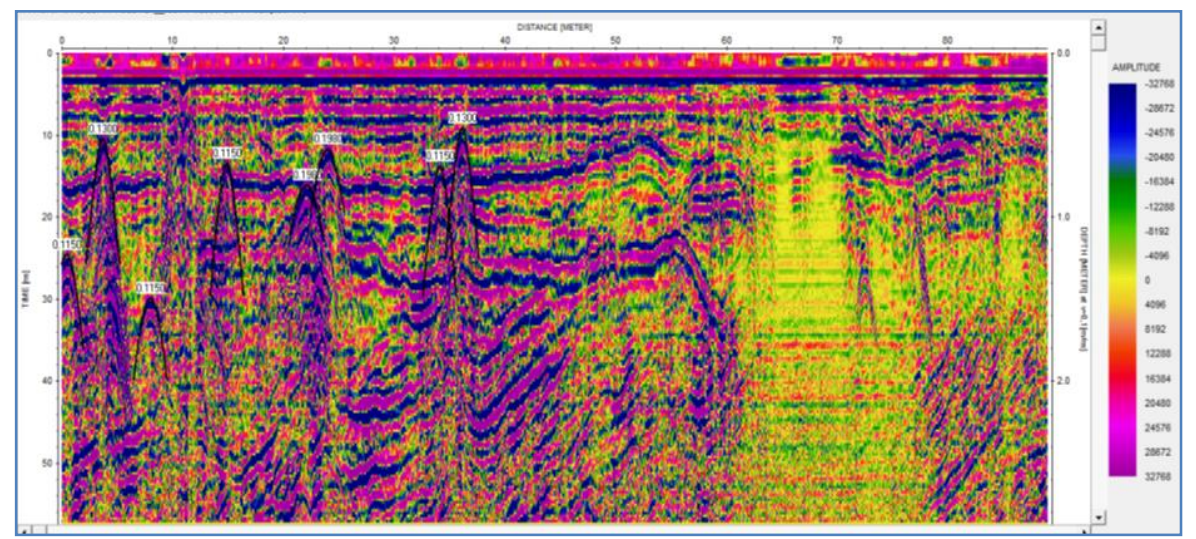

Gambar 3 Tampilan radargram lintasan 2 setelah proses background removal dan analisis kecepatan 


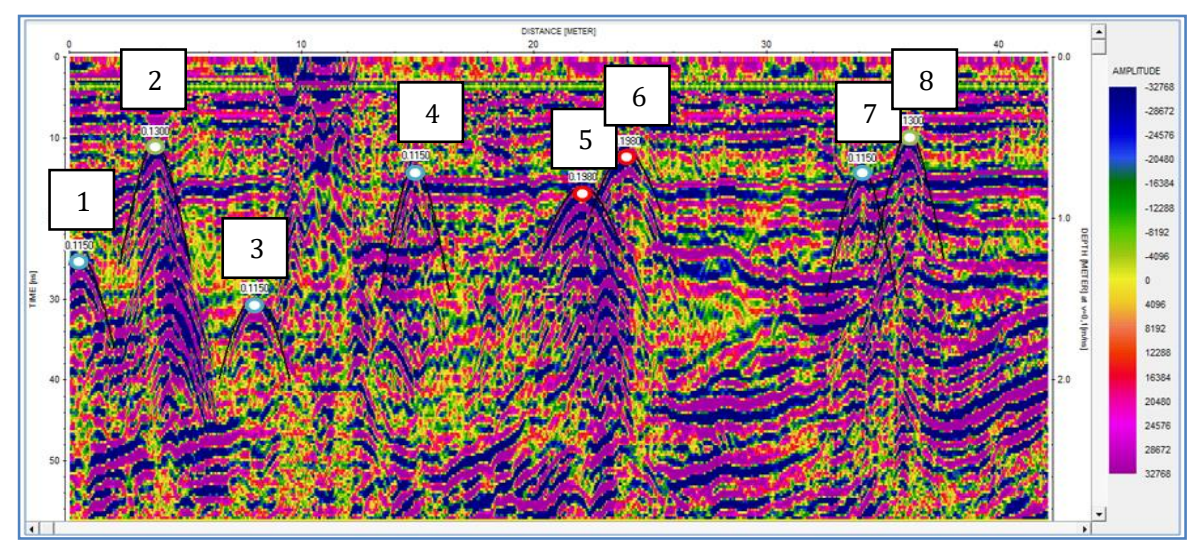

Gambar 4 Tampilan radargram lintasan 2 setelah proses migrasi

\subsection{Lintasan 3}

Pada Profil radargram lintasan 3 data diambil dengan menggunakan antenna transmitter berfrekuensi $500 \mathrm{MHz}$, dengan panjang lintasan 6,2 meter, dan kedalaman penetrasi gelombang elektromagnetik \pm 3 meter. Pada profil radargram yang telah diolah sampai pada tahap background removal dan analisis kecepatan (Gambar 5) terlihat anomali dengan bentuk refleksi hiperbola pada dua titik terjadi pada TWT 16 ns dan 14 ns. Setelah dicocokan dengan kurva kecepatan perambatan gelombang elektromagnetik pada material diperoleh nilai yang sama pada kedua titik yaitu $0,1500 \mathrm{~m} / \mathrm{ns}$.

Nilai kecerahan (amplitudo) yang cukup tinggi juga ditunjukan pada kedua pola refleksi dan lapisan bawah permukaan, hal ini menunjukan sifat material bawah permukaan berupa perbedaan nilai konduktivitas listrik dan konstanta dielektrik. Nilai konduktivitas listrik memiliki nilai yang berkebalikan dengan nilai konstanta dielektrik, kedua sifat material ini sangat mempengaruhi nilai kecerahan (amplitudo) pada hasil pengolahan data GPR. Nilai konduktivitas listrik material menunjukan kemampuan material dalam menghantarkan listrik. Material dengan nilai konduktivitas listrik tinggi seperti bahan-bahan logam akan menghasilkan nilai kecerahan (amplitudo) yang tinggi dan hampir sama dengan bahan-bahan PVC hanya saja nilai kecerahan (amplitudo) pada material PVC akan lebih rendah dibandingkan dengan bahan logam, begitu pula sebaliknya jika nilai konduktivitas listrik material rendah maka akan dihasilkan nilai kecerahan (amplitudo) yang rendah pula. Nilai konstanta dieletrik material memiliki hubungan dengan kecepatan perambatan gelombang elektromagnetik pada material, material dengan nilai konstanta dielektrik rendah memiliki kecepatan perambatan gelombang elektromagnetik tinggi begitu pula sebaliknya material dengan nilai konstanta dielektrik tinggi memiliki kecepatan perambatan gelombang elektromagnetik yang rendah, hal ini menunjukan bahwa nilai konstanta dielektrik material berbanding terbalik dengan kecepatan perambatan gelombang elektromagnetik pada material, namun untuk konduktivitas listrik material memiliki nilai yang berbanding lurus dengan kecepatan perambatan gelombang elektromagnetik pada material. Untuk nilai kecerahan (amplitudo) dengan nilai kecerahan tinggi memiliki arti bahwa material terdeteksi memiliki nilai konduktivitas listrik yang tinggi.

Pada profil radargram yang telah diproses sampai dengan tahap background removal dan analisis kecepatan akan dilakukan analisis terhadap refleksi dengan bentuk $\mathrm{U}$ atau $\mathrm{V}$ terbalik yang diduga sebagai refleksi kenampakan pipa yang berada dibawah permukaan. Nilai kecerahan (amplitudo) yang dihasilkan sangat tinggi hal ini menunjukan sifat konduktivitas bahan yang tinggi dan mengindikasikan bahwa objek yang terdeteksi berasal dari bahan logam. Pola refleksi hiperbola tersebut terlihat pada TWT 16 ns dan 14 ns, berdasarkan hasil pengolahan yang dilakukan pada proses analisis kecepatan dan pencocokan dengan kurva kecepatan diperoleh harga kecepatan 0,1500 m/ns. Hasil pencocokan dengan kurva kecepatan tersebut menunjuakan kecepatan yang tinggi dan bentuk hiperbola yang cukup luas hal ini mengindikasikan bahwa nilai konstanta dielektrik material yang terdeteksi bernilai cukup rendah. Pada kedua pola refleksi tersebut diperoleh bentuk yang sama. Pola refleksi yang terlihat pada TWT 16 ns dan 14 ns diindikasikan sebagai refleksi dari pipa PVC yang dipasang dibawah permukaan tanah dengan pemasangan yang dilakukan secara berdekatan. Pada TWT 16 ns keberadaan pipa diindikasikan pada jarak 2 meter dari titik awal pengambilan data dan kedalaman 0,8 meter dibawah permukaan. Sedangkan pada TWT 14 ns berjarak 3,2 meter dari titik awal 
pengambilan data dan pada kedalaman 0,68 meter dibawah permukaan. Kedua refleksi yang di hasilkan pada dua titik di lintasan3 memiliki nilai kurfa kecepatan yang sama hal ini mengindikasikan bahwa dua pipa yang di pasang berdekatan ini memiliki material pembuatan yang sama yaitu bahan PVC, bentuk refleksi hiperbola dan kecerahan (amplitudo) yang dihasilkan juga sama. Pada (Gambar 6) dapat dilihat hasil pengolahan data pada tahapan terakhir yaitu migrasi. Pada lintasan kedua ini juga digunakan migrasi dengan metode diffraction stack dengan nilai kecepatan yang digunakan yaitu $0,3 \mathrm{~m} / \mathrm{ns}$.

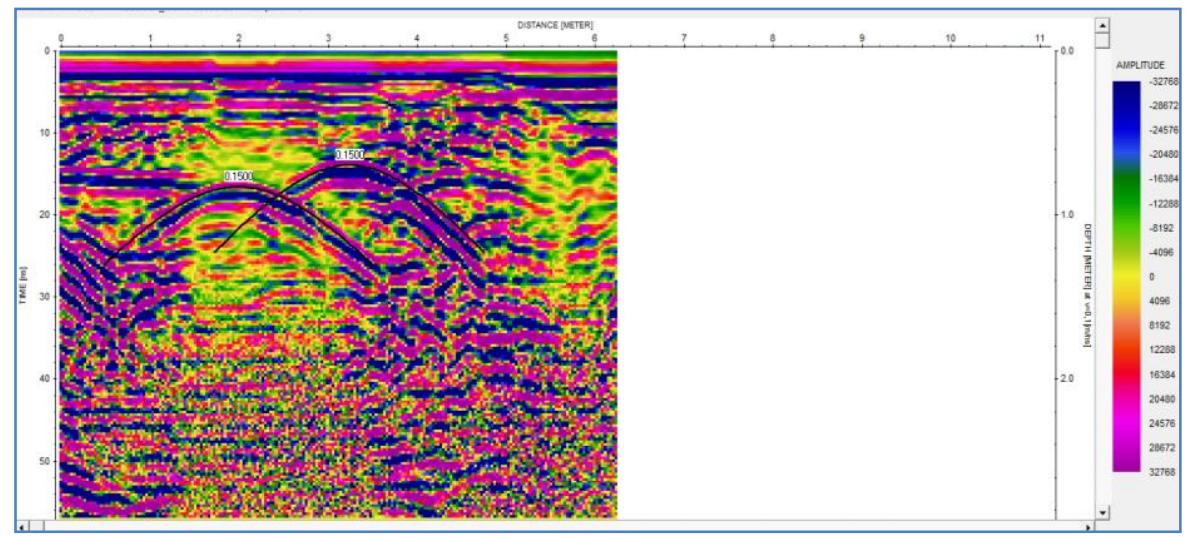

Gambar 5 Tampilan radargram lintasan 3 setelah proses background removal dan analisis kecepatan

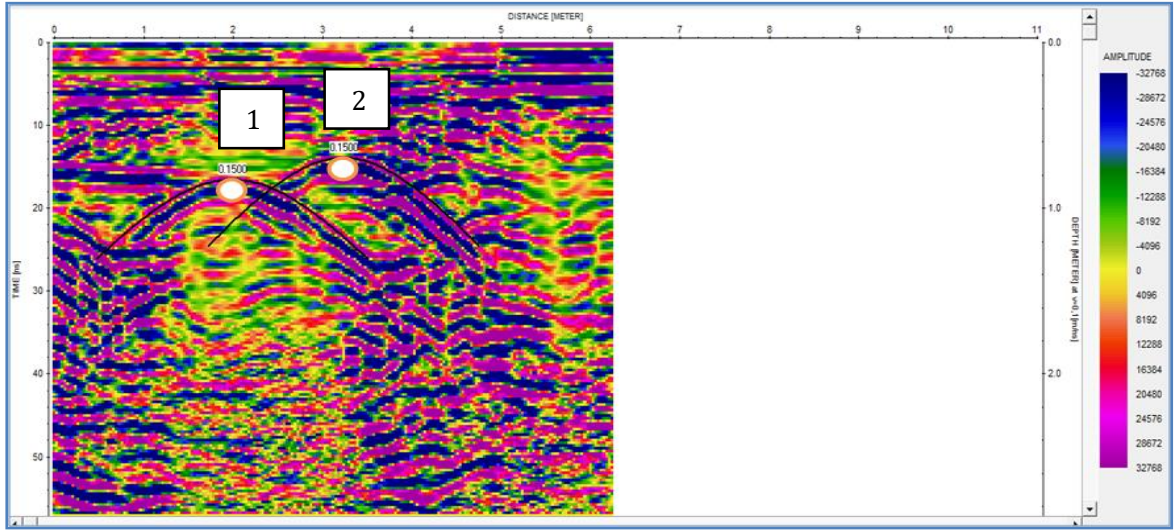

Gambar 6 Tampilan radargram lintasan 3 setelah proses migrasi

\subsection{Lintasan 4}

Panjang profil radargram lintasan 3 adalah 6,2 meter data diambil dengan menggunakan antena $500 \mathrm{MHz}$ diperoleh kedalaman penetrasi gelombang elektromagnetik \pm 3 meter. Pada penampang radar 2D lintasan 4, tidak ditemukan bentuk refleksi hiperbola. Hal ini menunjukan bahwa dalam radargram lintasan 4 tidak terdapat objek pipa yang ditanam dibawah permukaan. Namun jika dilihat terdapat kecerahan (amplitudo) yang cukup tinggi pada beberapa lapisan bawah permukaan yang di hasilkan pada radargam. Hal ini menunjukan bahwa pada beberapa lapisan bawah permukaan memiliki nilai konduktivitas yang cukup tinggi, namun pada lapisan bawah permukaan tidak ditemukan lapisan yang memiliki kemenerusan hal ini menunjukan bahwa sifat lapisan bawah permukaan yang heterogenesis. 


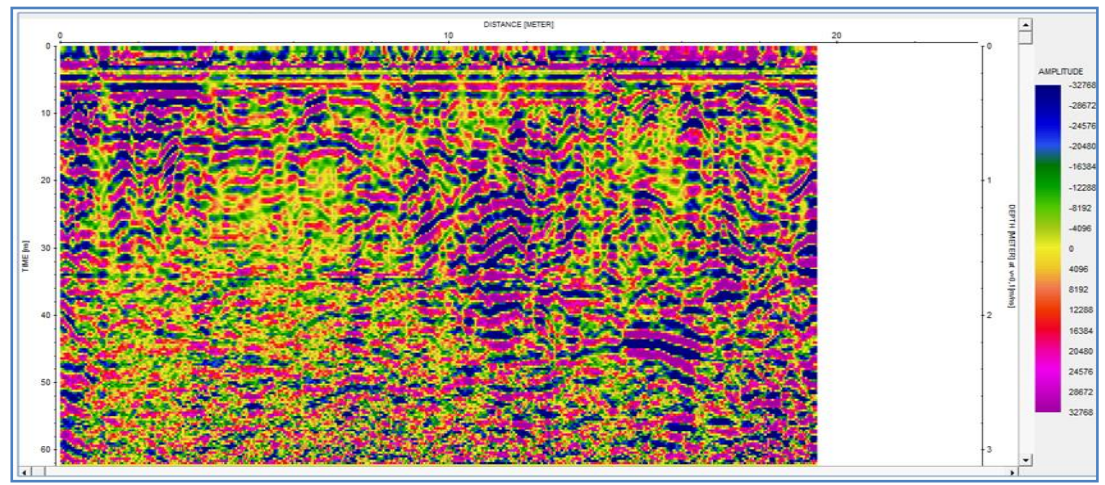

Gambar 7 Tampilan radargram lintasan 4 setelah proses migrasi

\section{Kesimpulan}

Berdasarkan penelitian yang telah dilakukan dapat disimpulkan bahwa :

1. Nilai kurva kecepatan perambatan gelombang elektromagnetik pada pipa metal adalah 0,1980 m/ns, dengan bentuk refleksi hiperbola yang luas, dan nilai amplitudo kecerahan yang tinggi.

2. Pada lintasan 1 diperoleh dua bentuk refleksi yang diduga sebagai titik keberadaan pipa metal, titik pertama berada pada jarak 72,15 meter dari titik awal pengambilan data pada kedalaman 0,704 meter dibawah permukaan dan TWT $14 \mathrm{~ns}$, serta titik kedua berada pada 73,78 meter dari titik awal pengambilan data pada kedalaman 0,754 meter dan TWT 15 ns.

3. Pada lintasan 2 diperoleh dua bentuk refleksi yang diduga sebagai titik keberadaan pipa metal, titik pertama berada pada jarak 22,05 meter dari titik pertama pengambilan data denga kedalaman 0,8 meter dibawah permukaan pada TWT $16 \mathrm{~ns}$, serta titik kedua terletak pada jarak 23,94 meter dari titik awal pengambilan data dengan kedalaman 0,6 meter dibawah permukaan pada TWT 11 ns.

\section{DaftarPustaka}

[1] Daniels, D.J., Ground Penetrating Radar. IEEE Radar Series. London. 2004

[2] Aji, S., Aplikasi Metode Ground Penetrating Radar Terhadap Pola Retakandi Bendungan Batu Tegi Lampung. Jurnal Departemen Pendidikan Fisika, FPMIPA Universitas Pendidikan Indonesia. Bandung. 2016.
[3] Syukur, M., Pemetaan Batuan Dasar Sungai Menggunakan Metode Ground Penetrating Radar. Skripsi Program Studi Geofisika Universitas Indonesia. Depok. 2009.

[4] Fadlan, M, Intan, S., Georadar dalam Penelitian Arkeologi di Indonesia. Jurnal Pusat Penelitian Arkeologi Nasional. Jakarta. 2016.

[5] Reynolds, J.M., An Introduction to Applied and Enviornmental Geophysics. Chicester. England. 1997.

[6] Azizah., Pemfokusan Citra Radar Untuk Hasil Pemodelan Radar Penembus Permukaan Menggunakan Algoritma Migrasi Jarak. Jurnal ELKOMIKA. Bandung. 2016; Vol: 4; No:1; Hal:110-122.

[7] Warana.D.D., Identifikasi Scouring Sebagai Potensi Kelongsoran Tanggul Sungai Bengawan Solo Berdasarkan Survei GPR (Studi Kasus Desa Widang, Kabupaten Tuban). Jurnal Jurusan Fisika Institut Teknologi Sepuluh November. Surabaya. 2008; Vol : 4; No:2.

[8] Anggi, S.N., Deteksi Keberadaan Endapan Bauksit Laterit dengan Pemanfaatan Gelombang Radar. Skripsi Program Studi Fisika, Fakultas Matematika dan Ilmu Pengetahuan Alam Universitas Indonesia. Depok. 2009.

[9] Kuseno, T., Aplikasi EM-Conductivity Sistem Loop Vertical Coplanar untuk Identifikasi Sebaran Pupuk pada Lahan Pertanian di Sungai Raya, Kubu Raya, Kalimantan Barat. Jurnal Program Studi Fisika Fakultas MIPA Universitas Tanjungpura. Pontianak. POSITRON, Vol. IV, No. 1 (2014), Hal. 01 - 06. 
[10] Budiono, K., Hernawan, U., Godwin., Penafsiran Geologi Bawah Permukaan Lumpur Lapindo Sidoarjo Berdasarkan Penampang Ground Penetrating Radar (GPR). Jurnal Geologi Indonesia, Penelitian dan Pengembangan Geologi Kelautan (PPPGL) Bandung. Bandung. 2010; Vol: 5 ; No: 3.

[11] GSSI Hanbook for Radar Inspection of Concerte. Geophyisical survey System, Inc. 2001.

[12] GSSI Hanbook for Radar Inspection of Utility. Geophyisical survey System, Inc. 2016. 